Charles T. GARTEN \& Michael H. SMITH

\title{
MOVEMENT BY OLDFIELD MICE AND POPULATION REGULATION
}

RUCHLIWOSC PEROMYSCUS POLIONOTUS A REGULACJA LICZEBNOSCI POPULACJI

Superposing annual patterns of oldfield mouse movement and population numbers indicates emigration is important in limiting peak densities however, emigration apparently is not the major cause of declining population numbers following peak densities.

Dispersal from small mammal populations is one process affecting and possibly limiting population numbers (Lidicker, 1962; Myers \& $\mathrm{K}$ rebs, 1971). Prohibiting emigration and immigration by enclosing a population with a fence is one technique used to investigate the importance of dispersal as a regulating agent. Fenced populations increase to abnormally high densities and fencing appears to inhibit natural regulating mechanisms ( $\mathrm{K} \mathrm{r} \mathrm{e} \mathrm{bs}$ et al., 1973). When emigration is an important cause of periodic declines in small mammal density, then increased movement should accompany decreasing population numbers. However, dispersal in voles is not associated with population declines, but is most common when numbers are increasing (Meyers \& Krebs, 1971). Capture techniques used to measure dispersal in voles (M yers \&

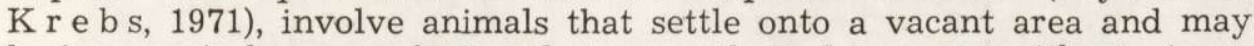
be inaccurate because of mice that move through an area without stopping.

A better technique for measuring small mammal movement is the use of pitfall traps with drift fences (B rie se \& S m i th, 1974). Movement into and out of an oldfield mouse population (Peromyscus polionotus) has been measured by pitfall trapping throughout a complete year on the Savannah River Plant in South Carolina. The drift fence, which enclosed a 1.8 ha field, was $40 \mathrm{~cm}$ high with pitfall traps at periodic intervals. The total number of mice captured in the traps each month indicates that the amount of movement varies seasonally with peak movement occurring in late fall (Briese \& S mith, 1974). Numbers of mice are not known for the entire year during which movement data were collected. However, regular fluctuations in oldfield mouse numbers on the same study area have been observed over a separate three year period ( $\mathrm{S} \mathrm{m} \mathrm{i} \mathrm{th,1971).} \mathrm{An}$ average cycle based on two complete consecutive years shows an autumn increase, an early peak in winter, a late peak in early spring, a spring decline, and a summer low in numbers (Fig. 1). Captures on the drift fence surrounding the oldfield reflect increased movement by mice at the time of the year when numbers are increasing. Peak movement occurs just prior to the early peak in population numbers. There is minimal movement by oldfield mice during the late peak and spring decline in population size. The data from different time periods are considered compatible in this case because seasonal fluctations in oldfield mouse numbers are extremely regular from year to year (S m it h, 1971).

Increased movement is indicative of dispersing mice during the increase phase. Dispersal appears to have a damping effect on the peak in oldfield mouse population numbers. Immediately after the peak in movement activity, numbers level out for a couple of months. Movement during the 
increase phase probably counteracts the effects of inbreeding and assortative mating of oldfield mice (Smith, Carmon \& Gentry, 1972) by increasing gene flow. Otherwise inbreeding will tend to steadily depress the overall fitness of the population.

Lack of movement by oldfield mice during the late peak and the decline phase indicates decreasing population numbers are not attributable to increased emigration. It is more likely that increased mortality, possibly

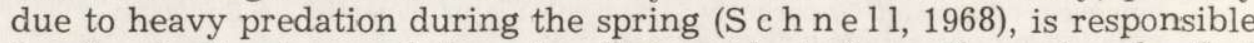
for the decline in population size. It is evident from these trends that emigration is important in limiting population densities by depressing

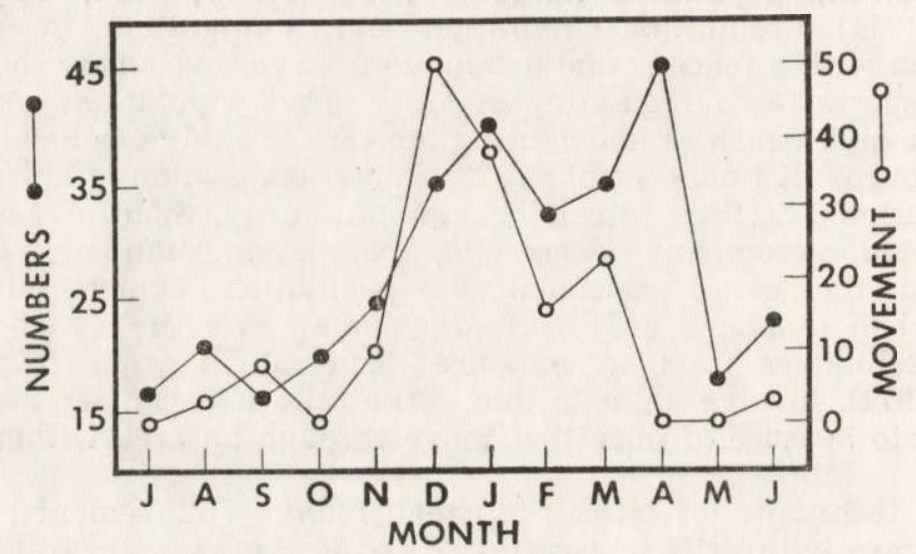

Fig. 1. Average oldfield mouse numbers each month based on two consecutive years (1967-68; S mith, 1971) and oldfield mouse movement each month for one year (1971-72; B riese \& S mith, 1974). Movement is expressed as the number of mice captured in pitfall traps along a drift fence surrounding the population.

peak numbers, but as in vole populations, emigration or dispersal by oldfield mice does not appear to be the mechanism causing a regular decline in population numbers.

This work was supported by Contract No. AT (38-1)-819 between the U.S. Atomic Energy Commission and the University of Georgia.

\section{REFERENCES}

Bries e L. A. \& M. H. S mith 1974: Seasonal abundance and movement of nine species of small mammals. J. Mammal., In Press. Krebs C. J., M. S. G a in e s, B. L. Kelle r, J. H. M e yers, \& R. H. T a marin, 1973: Population cycles in small rodents. Science, 179: 35-41. L i d i cker W. Z., Jr. 1962: Emigration as a possible mechanism permitting the regulation of population density below carrying capacity. Amer. Nat., 96: 29-33. M y e r s J. H. \& C. J. K re b s, 1971: Genetic, behavioral, and reproductive attributes of dispersing field voles, Microtus pennsylvanicus and Microtus ochrogaster. Ecol. Monogr., 41: 53-78. S chnell J. H., 1968: The limiting effects of natural predation on experimental cotton rat populations. J. Wildl. Mgmt., 32: 698-711. Smith M. H., J. L. Carmon \& J. B. Gentry, 1972: Pelage color polymorphism in Peromyscus polionotus. J. Mammal., 53: $824-833$. S m ith M. H., 1971: Food as a limiting factor in the population ecology of Peromyscus polionotus (Wagner). Ann. Zool. Fennici, 8: 109-112.

Savannah River Ecology Laboratory, P. O. Drawer E, Aiken, South Carolina 29801. Accepted, June 22, 1974. 